\title{
SOUTH AFRICA'S TWO TRACK APPROACH TO SCIENCE DIPLOMACY
}

\author{
Lesley Masters ${ }^{1}$
}

There is nothing more international than science - Henry Kissinger

\begin{abstract}
While debate continues around the usefulness of the concept of Science Diplomacy, in practice international scientific relations are already facilitating diplomatic engagement, and diplomatic relations are supporting international scientific engagement. This interaction takes place in the context of the current global knowledge structure where industrialised or developed states are the "producers" of knowledge, and developing states the "consumers". With science, technology and innovation integral to addressing transnational challenges, this article considers the expanding body of literature, which is primarily from developed states, highlighting the shortfall in understanding the role of developing states in science diplomacy. The article then considers developments in South Africa's science diplomacy, arguing that Pretoria demonstrates a two-track approach; one that reflects the state's pursuit of international recognition as a "producer" and exporter of knowledge at the centre of the global knowledge structure; and the second, where a shortfall in capacity and resources has increasingly seen the state as a "consumer" or importer of knowledge in meeting domestic priorities.
\end{abstract}

Keywords: Science diplomacy; diplomacy; global knowledge structure; South Africa; foreign policy; science, technology and innovation.

Sleutelwoorde: Wetenskaplike diplomasie; diplomasie; globale kennisstruktuur; Suid-Afrika; buitelandse beleid; wetenskap, tegnologie en vernuwing.

\section{INTRODUCTION}

With science, technology and innovation becoming increasingly central to addressing a number of domestic and transnational challenges from climate change to nuclear non-proliferation, the idea of "Science Diplomacy" is gaining traction in the lexicon of international relations. While there is a debate among academics, diplomatic practitioners and scientists on what the concept means, its approach and its impact, what is not apparent within these discussions is the role of science diplomacy in the

1 Senior Researcher and Senior Lecturer, SARChI Chair: African Diplomacy and Foreign Policy, University of Johannesburg. E-mail: 1masters@uj.ac.za. The author wishes to thank the anonymous reviewers for their comments and suggestions.

2 For purposes of this analysis, "Science Diplomacy" is used as an inclusive term for science, technology and innovation. 
global knowledge structure. This is important because, as Vorster and Nel (1995:52) point out, "the power which constitutes science does have an international dimension to it" (italics in original).

In her analysis, Susan Strange (2015:31-35) sets out four sources of power in international relations: security, production, finance, and knowledge. When it comes to knowledge, she notes that, "knowledge is power and whoever is able to develop or acquire and to deny the access of others to a kind of knowledge respected and sought by others; and whoever can control the channels by which it is communicated to those given access to it, will exercise a very special kind of structural power" (Strange 2015:33).

Discussions around the concept of science diplomacy are predominantly located within developed or industrialised states, with relatively little input from developing states. ${ }^{3}$ When it comes to explaining this shortfall, particularly in the context of Africa, Makinda, Okumu and Mickler $(2015: 163,165,168)$ argue that, "Africa's abject poverty and the lack of global influence appear to stem in part from its weak knowledge base in science, technology, and innovation", and that within the global knowledge structure, "Africa remains on the scientific, technological, economic, political, and military margins of the world largely because it is a net consumer - rather than a producer - of usable knowledge".

In other words, developing states find themselves in a position where, as "consumers" of knowledge, the emphasis is on attracting science, technology and innovation in support of their development priorities, rather than exporting, presenting, or "producing" their own knowledge. This is a position reflected in the analysis by Flink and Shreiterer (2010:665-677), where emerging states such as Brazil, Russia, India and China (BRIC) are considered "target markets", rather than as actors engaged in horizontal and reciprocal science diplomacy. At the outset this article considers the concept of science diplomacy as it has emerged within the discourse. The analysis then goes on to consider South Africa's science diplomacy approach given its position as a developing state within the global knowledge structure.

\section{SCIENCE DIPLOMACY AND THE GLOBAL KNOWLEDGE STRUCTURE}

There is a growing trend in the field of Diplomacy (analysis and practice) that identifies modes, issue areas and tools of diplomacy. For instance, in The Oxford handbook on modern diplomacy (2013), Humanitarian Diplomacy and Defence Diplomacy are listed as modes of diplomatic practice; Economic Diplomacy and

3 Examples of contributions from the geo-political South include Zahuranec, Ittekkot and Montgomery 2014; Treacy 2015. 
Cultural Diplomacy are listed as tools and instruments of diplomacy; while Trade Diplomacy, Health Diplomacy and Refugee Diplomacy are referred to as issue areas of diplomacy. The concept of science diplomacy is used within the literature on the subject to include, "the use of scientific collaborations among nations to address the common problems facing $21^{\text {st }}$ century humanity and to build constructive international partnerships" (Fedoroff 2009:9). While this definition is limited in scope by its statist approach, despite a number of non-state actors engaged in science diplomacy, it does reflect the importance of international cooperation.

In the report, New frontiers in Science Diplomacy (AAAS and the Royal Society 2010:v-vi), three elements comprising science diplomacy are laid out. Firstly, "science in diplomacy", or where science underpins negotiations. For example, in the case of climate science, where the science calls for a cap on emission in order to ensure that temperatures remain below the $2^{\circ}$ Celsius base mark in an effort to avoid irreparable damage. This provides a scientific benchmark around which negotiations continue. Secondly, there is "diplomacy for science" where diplomacy is used to facilitate scientific cooperation, for instance, the negotiations that took place in order to secure the Square Kilometre Array (SKA) telescope in South Africa. Finally there is "science for diplomacy" where scientific cooperation supports improved relations between states, such as the international space cooperation between the United States of America (US) and the Union of Soviet Socialist Republics (USSR) during the height of the Cold War.

Delineating issues, modes and tools within the broader field of Diplomacy, such as environmental diplomacy, nuclear diplomacy, or in this case science diplomacy, allows for a particular focus on an area of increasing knowledge specialisation within international relations; specialisation which requires an understanding of the technical details across scientific debates and the geo-political context in which these negotiations take place. In this article the focus on science diplomacy allows for analysis of international relations focused on achieving a particular political and scientific end, and the interactional dynamics between parties looking to cooperate on questions of science, innovation, and technology.

In their analysis of science diplomacy, Turekian and Neureiter (2013:28) argue that, "[s]cience and its applications are central to almost every major global challenge"; however, its development and application are experienced differently by developed and developing countries within the wider international knowledge structures of power. These differences have implications for diplomacy where, for example, without detailed knowledge of a particular issue area, there is significant potential for misunderstanding and failure to negotiate an agreement that is beneficial to all parties. This is already evident in the climate change negotiations under the United Nations Framework Convention on Climate Change (UNFCCC). Representatives from developing, and least developed states in particular, do 
not always have the necessary levels of knowledge on the particular areas being negotiated, leaving them with limited scope to ensure effective participation and the best outcome for their country position (Chasek and Rajamani 2002). Science and technology has also been a source of tension between developed, emerging and developing states at the climate change negotiations, as developing countries call for technology transfer and capacity building, while developed and emerging states raise concerns around issues such as the protection of intellectual property rights.

The idea of science diplomacy is itself not new, with the literature pointing out that the US was among the first to make use of a science attaché, having representation in Germany as early as 1898 (Linkov et al. 2014). Arguments for why it is gaining traction in international relations today include: 1) globalisation and increased technological connectivity; 2) a rise in transnational environmental and technological threats; 3 ) the growing number of developing state and non-state participants in science and technology; 4) the proliferation of small collaborative transnational research; and 5) the need for an "internationally knowledgeable workforce" (Linkov et al. 2014).

The literature does not, as yet, adequately address the impact of the inequality represented by the global structure of knowledge on the role of developing states as they too look to engage in science diplomacy. Developed states have been able to give particular attention to building capacity when it comes to science diplomacy. For example, in the case of the US, following a study that demonstrated that 13 out of the 16 foreign policy goals had direct science consideration, attention was given to the creation of the position of science advisor to the Secretary of State and the inclusion of more scientists in the State Department and United States Agency for International Development (USAID) (Turekian and Neureiter 2013:28). The Japanese Council for Science and Technology Policy has framed science and technology as, "an emerging field of IR [international relations] in which 'soft power' would play an ever bigger role" (Flink and Schreiterer 2010:666), with the Japanese Ministry of Foreign Affairs dispatching science and technology officers as science attachés to 27 different missions (Yakushiji 2009:2). In 2000 the United Kingdom (UK) set up a Science and Innovation Network with a number of postings abroad, replacing the former science counsellors of the Foreign Office. This was also the year that the US established the post of Science and Technology Advisor to the State Department (Flink and Schreiterer 2010:666).

Science diplomacy is also conducted within international multilateral forums. As the United Nations (UN) represents the most inclusive platform for engagement (despite its limitations), it is considered a critical forum for developing states' participation. Nevertheless, as Vorster and Nel (1995:56) argue, structural inequalities persist within these multilateral platforms where developed states have, "acquired the means to prescribe, by and large, what should count as noteworthy 
S\&T [science and technology] activities". While the UN, and its specialised agencies, such as the World Meteorological Organization (WMO), the United Nations Educational, Scientific and Educational Organization (UNESCO) and the UN Science and Technology Diplomacy Initiative falling under the SecretaryGeneral of the UN Conference on Trade and Development (UNCTAD), may be seen as important platforms for engagement on international science and technology, they are also sites of tension in the practice of science diplomacy. This includes the ability of developed states to shape the agenda through their intellectual, institutional and financial resources, driving the "internationalisation" of science and technology indicators that reflect their priorities (Vorster and Nel 1995:55, 58).

Science diplomacy is not only conducted at the level of states. With a growing divide between the "haves" and "have nots", and the prominence given to the role of science, technology and innovation in addressing issues of human security, non-state actors, including civil society, the private sector, academia and research organisations, have been drawn into international debates and scientific collaboration. The more prominent and active non-state actors in science diplomacy are, however, primarily from developed states. For example, the US has seen a growth in the role of non-governmental actors in international science relations including the Federation of American Scientists (FAS), CRDF Global, ${ }^{4}$ the National Academy of Sciences (NAS) and the American Association for the Advancement of Science (AAAS) (Kramer 2010:28). The AAAS has itself launched the Centre for science diplomacy in 2008 (Holt 2015).

The value of this "track-two", or un-official level engagement, is that government involvement may raise suspicions around the motives for cooperation. As non-state actors do not represent official positions, it is possible for them to engage in a frank exchange of ideas with their counterparts. As one commentator noted, "nongovernmental organizations are key to successful science diplomacy. 'Anything that smacks of the US government trying to implement something in another country is [seen as] manipulative and suspect, even if [it is] done with the best intentions" (Kramer 2010a:30). It is argued that part of the value of science diplomacy is that collaboration across technical and scientific areas is made possible because, "[s]cientists and engineers share a set of values which is pretty much independent of culture" (Kramer 2010a:29) and since "scientists speak a universal language", it will support collaborations and bridge-building between states (Kramer 2010a:30). However, caution should be raised at such generalisations. Given the global knowledge structure, there is often suspicion around the motives of developed states (and former colonisers), as these scientific collaborations may also serve to impose a specific approach to knowledge reflecting their interests (Treacy 2015).

4 CRDF Global was originally called the U.S. Civilian Research and Development Foundation for the Independent States of the Former Soviet Union (CRDF). 
Flink and Schreiterer (2010:669) identify three goals of science diplomacy: 1) access to researchers, research findings, facilities, natural resources and capital; 2) the promotion of the state through highlighting research and development (R\&D) achievements and attracting the best students, researchers and companies; and 3) influence of another state's public opinion, decision-makers and political or economic leaders. Rather than building a diplomatic "bridge", these goals may sow greater division between developed and developing states, given the international knowledge structure. For instance, as developed states look to attract capacity and resources, it is often at the expense of developing states which are losing students, researchers and companies to better resourced states. In addition, developing states are often the hosts of scientific investigation, but have little input into the design or implementation of research projects. In this context, science diplomacy may be exploitative or transactional in pursuit of foreign policy priorities (Annegarn and Swap 2012).

\section{SOUTH AFRICA'S EVOLVING SCIENCE DIPLOMACY: FROM ISOLATION TO PARTICIPATION}

South Africa's approach towards science diplomacy is shaped by its past and present, as well as its domestic and international environment. Internationally isolated in response to the domestic policies of apartheid, South Africa pursued science and technology solutions to mitigate the impact of sanctions with particular attention given to the state's security through technologies such as iron processing and steel production, energy security, nuclear technology and bio-warfare technology (Simelane 2015:43). During this period South Africa's focus on the development of domestic capacity in science and technology resulted in a number of advances in sectors such as nuclear technology, coal-to-liquid (CTL) processing in producing oil (as South Africa has yet to find any natural oil reservoirs), and undertaking the first human-to-human heart transplant at the Groote Schuur Hospital. This saw the country achieve international scientific recognition, a knowledge "producer", despite its isolation (Simelane 2015:41).

Following the democratic transition in the 1990s, there has been a shift from the parochial pursuit of technological advancement in response to the growing number of sanctions against apartheid to positioning the country within the growing bilateral and multilateral science and technology landscape. Already the country is party to a number of international projects in space science and technology, hydrogen and energy, biotechnology and health innovation, innovation planning and instruments, and in radio astronomy through the SKA (NPC 2011:326). In her analysis of South Africa's science diplomacy, Minister for Science and Technology, Naledi Pandor (2012), sets out that, "South Africa's priorities for science diplomacy can perhaps best be summed up by stating that international scientific 
cooperation is pursued both as an objective in its own right and as an instrument to attain strategic national and foreign policy objectives". She goes on to indicate that Pretoria's agenda encompasses the three elements of science diplomacy science in diplomacy, science for diplomacy and diplomacy for science. This, "has achieved success in three areas: (a) diplomatic efforts to promote international scientific cooperation; (b) international scientific cooperation to address political and economic developmental goals related to foreign policy; and (c) the science content of topical international relations issues and the diplomatic effort required to deal with them" (Pandor 2012).

Acknowledging the importance of international engagement in developing the knowledge economy for the future of South Africa, the Department of Science and Technology (DST) saw, as among its first priorities, the need to develop and implement a strategy for international cooperation (Pandor 2012). The DST has subsequently been central in the promotion of international scientific cooperation with a separate Programme for International Cooperation and Resources which aims to, "[s]trategically develop, promote and manage international relationships, opportunities and S\&T [science and technology] agreements that strengthen the national system of innovation (NSI) and enable an exchange of knowledge, capacity and resources between South Africa and its regional and international partners. The Programme also supports South African foreign policy through science diplomacy" (DST 2011).

These objectives are supported by three sub-programmes: 1) International Resources; 2) Bilateral Relations; and 3) Multilateral Cooperation and Cooperation with Africa. The active role South Africa pursues within the science diplomacy landscape is evident in the work of the division for Bilateral Relations, which has been active in strengthening relations with both developed states, such as the US and the UK through new frameworks of bilateral cooperation, and new partnerships with Norway, Sweden, Finland, Switzerland, the Republic of Korea, the European Union (EU), as well as with developing states such as Argentina and Jamaica (DST 2014a:9, 78). The work of the Sub-Programme for Multilateral Cooperation and Cooperation with Africa, is also engaged in managing South Africa's participation in the Organisation for Economic Cooperation and Development (OECD) development discussions, including discussions on how best to cooperate in research in an, "effort to ensure science and innovation was at the heart of the post-2015 development agenda of the United Nations" (DST 2014a:79). South Africa has also served as the Chair of the Non-Aligned Movement (NAM) Centre for Science and Technology (DST 2014a:9), and is represented in the International Atomic Energy Agency, the African Regional Cooperation for Research, Development and Training related to Nuclear Science and Technology, the African Ministerial Council on Science and Technology (Simelane 2015:41). The DST has "strategic partnerships" with the European Centre for Nuclear Research in 
Geneva, the international Centre for Genetic Engineering and Biotechnology in Trieste, and the Group on Earth Observation (GEO). In 2013 the DST DirectorGeneral assumed the Presidency of the Science Commission of UNSECO. This is the first time an African had chaired a UNESCO Commission (DST 2014a:79).

While South Africa does have three science and technology positions within the diplomatic missions in Tokyo, Moscow and Brussels (Pandor 2012), there is concern regarding expanding the capacity of the DST. This has seen calls for the use of existing government infrastructure and the networks of other government departments abroad for international engagement (DST 1996). In support of this position the 2000-2001 Annual Report of the DST called for a more integrated approach towards international relations in science and technology. This included the drafting of a manual on the Purpose of Conducting Bilateral International Scientific and Technological Cooperation (DST 2001:105), although relations have already developed beyond what this manual envisioned (DST 2015).

Recognising the increasing role of actors beyond the central state apparatus, the DST has entered into partnerships with businesses, such as Anglo America, and state owned enterprises, including Eskom, Transnet, and Sasol (DST 2014a:7-8). The Department also has a number of institutions and research organisations that fall within its remit, but which themselves act as agents within the international milieu, including the Council for Scientific and Industrial Research (CSIR), the National Research Foundation (NRF), and the Human Sciences Research Council (HSRC). Relations between the DST, the institutions it supports, and the Department of International Relations and Cooperation (DIRCO) have been described as good, with regular meetings taking place between the heads of these institutions to share information. Representatives from these institutions have also been included in the international delegations of the DST (DST 2015).

It is acknowledged, however, that there is scope for further advancing awareness of the value of science diplomacy through the inclusion of the subject in diplomatic training programmes (DST 2015). Certainly the linkages between science and foreign policy has seen the Minister for Science and Technology urging collaboration between her department and DIRCO in pursuit of international partnerships in science, technology and innovation (Pandor 2014a).

\section{SOUTH AFRICA'S SCIENCE DIPLOMACY IN PRACTICE: A TWO-TRACK APPROACH}

With expanding international partnerships, which have seen more than 2000 international cooperation opportunities during the 2013-2014 period (DST 2014a:78), science diplomacy is seen as a particular area of growth in South Africa's strategic international cooperation. What distinguishes international scientific collaboration from science diplomacy is the nexus between science and diplomacy in the case of the 
latter, where engagement is aimed at building and sustaining relations. For instance, while there may be a number of examples of scientific collaboration between South Africa and Europe, not all examples constitute science diplomacy. One example where science diplomacy is coming to the fore, is in resolving the growing acrimony in South Africa-EU trade relations in the case of the citrus black spot, where the EU stopped the import of South African citrus for fear of infecting their own orchards. This is perceived by South Africa as yet another form of market protectionism, given that the industry has spent over R1bn during the course of 2014/2015 in an effort to comply with European regulations. In an effort to address growing tension, industry specialist, Deon Joubert, headed a delegation to the EU in the hopes of normalising trade, and shedding "some light and perhaps provide clarity and convergence of scientific evidence on the matter" (Magwaza 2015). In this instance science is providing the platform for discussion and the prospect for the normalisation of relations, particularly as the EU's own report from the Food and Veterinary Office, "further supported scientific evidence the fungus was not harmful to European orchards" (Magwaza 2015).

Other examples of South Africa's science diplomacy include the Southern African Regional Science Initiative (SAFARI 2000), where science was used to bring together expertise in promoting research across the Southern African region, while the SKA is an example of South Africa's science diplomacy where international negotiations secured the building of the radio telescope in Africa (and Australia and New Zealand). The precursor array to the SKA, the MeerKAT, which should be completed by 2016, already has some 500 time slots allocated with bookings five years in advance (DST 2014a). South Africa's Minister for Science and Technology has set out that, "[k]nowledge is the currency of the global economy. If South Africa wants to continue to compete in the $21^{\text {st }}$ century, we must support research and innovation that will generate growth and jobs, now and in the future" (cited in Wild 2015).

This recognises not only the importance for South Africa in engaging in the changing science, technology and innovation landscape, but also the challenges of doing so within the current global knowledge structure. Given its current domestic priorities and international position as an "emerging state", South Africa's science diplomacy reflects a two-track approach. The first is South Africa's use of science diplomacy in support of a strategic international position within the current global structure, where a position as a "producer" and exporter of knowledge is pursued. The second track aims to address the increased challenges facing the state as a "consumer", or attracting and importing knowledge, as South Africa increasingly competes with other developing countries for access to capacity development and resources.

Perceptions of South Africa as an "producer" and exporter of knowledge are evident in the position set out by the DST; that its international relations programme 
aims to position the state in shaping, "regional, continental and global STI [science, technology and innovation] discourse, decision making and policy formulation using science diplomacy to ensure that the interests of South Africa are represented" (cited in Wild 2015). At the same time, South Africa's position also reflects the state as a "consumer" and an importer of knowledge as, in achieving the goals of its science diplomacy, the Sub-Programme for International Resources works to attract and enhance the flow of resources to South Africa, including access to international, "research funding, knowledge networks, research infrastructure and institutions, policy discourses, and official development assistance" (DST 2014a:44, 78).

\subsection{Science diplomacy and strategic international positioning: South Africa as a knowledge "producer"}

Given the unequal playing field when it comes to developing and accessing science and technology, science diplomacy is seen as a means of strategically positioning the state in the international milieu. South Africa's approach to science diplomacy, particularly during the first decade following the democratic transition, focused on advancing the country's position within the international science, technology and innovation landscape. The importance of the ability to compete internationally is evident in the 1996 White Paper on Science and Technology, which notes that the country, "has a proud record of quality basic research and it is important to sustain this. In particular, the bridge that such research provides to the international scientific environment must be preserved. It is the quality of our science rather than the number of international agreements we are party to which will ensure this" (DST 1996).

While the White Paper may have given priority to the quality of science, rather than the pursuit of agreements, South Africa has signed agreements with 19 states across Africa (Simelane 2015:49). Other forms of engagement have taken the shape of sending officials from the DST on secondment to the Southern African Development Community (SADC), becoming the founding Chair of the African Ministerial Council on Science and Technology, and investing, "significantly in pan-African initiatives such as the African Laser Centre and the African Institute of Mathematical Sciences" (Pandor 2015). The importance of promoting South Africa's own developments in science and technology is evident in the National Development Plan (NDP), which notes that in, "areas such as science, culture, higher education, sport and environmental protection, there is a need to showcase South Africa and promote its presence and leadership on strategic issues as part of its 'soft power' in international relations" (NPC 2011:241).

Regional examples of science diplomacy in positioning South Africa as central in promoting scientific collaboration (and knowledge development) include SAFARI 2000. This saw collaboration among 200 scientists from across 16 states between 1998 and 2003 in a study of the impact of aerosol and trace gas 
emissions on the regional climate (Annegam and Swap 2012). Nevertheless, while the focus was on scientific collaboration, the SAFARI project, which was funded by the US National Science Foundation and the National Aeronautics and Space Administration (NASA), raised suspicion among South African cabinet members that the research was a cover for US surveillance activities in the region that would disadvantage developing states in the climate change negotiations (Annegam and Swap 2012). Suspicion around motivations for scientific collaboration is not, however, only limited to developed countries. South Africa too faces suspicion from the continent around its science activities given the country's destabilising influence during its apartheid past.

In building a recognised role in the current global knowledge structure, South Africa has given particular emphasis to strengthening relations with the geopolitical South. As Naledi Pandor (2012) indicates, "the fostering of South-South relations is an increasingly important strategic priority for South Africa in politics and trade, but also in science". Science occupies a position in both the India, Brazil and South Africa Trilateral Dialogue Forum (IBSA), through the working group on Science and Technology and Information Society, and as part of South Africa's engagement with BRICS (Brazil, Russia, India, China and South Africa). As relations with BRICS gain in prominence during the Zuma administration, this platform for cooperation has also seen the inclusion of science, technology and innovation as areas of priority. South Africa hosted the first meeting of the BRICS Science, Technology and Innovation Ministers in February 2014 (DST 2014a:9). By the second BRICS ministerial meeting in March 2015, a memorandum was signed, reflecting the objectives of science cooperation by strengthening cooperation and addressing global and regional socio-economic challenges through "shared experiences and complementarities" (Pandor 2015).

Beyond these trilateral and multilateral platforms, South Africa has sought to use cooperation agreements on science in strengthening bilateral relations with developing states such as Cuba (where there are strong historical ties), with former President Thabo Mbeki signing a science and technology cooperation agreement in 2001. South Africa has also sought to engage states such as the Republic of the Sudan in scientific collaboration through the Bilateral Science and Technology Agreement. Signed in November 2014, this agreement aims to build collaboration in areas such as nanotechnology, energy, health, agriculture and animal resources, climate change, intellectual property and human capital (Pandor 2014b).

South Africa's emerging role as a development assistance partner in SouthSouth cooperation has also seen a role for science diplomacy in "producing" and exporting South Africa's achievements in science and technology (DST 2015). Developed states have already made the link between development assistance and science diplomacy. 
USAID looks to attract scientists and engineers with the unveiling of a "development innovation ventures fund" that would support the development of new high-risk technologies that would have application for the developing world (Kramer 2010b:30). A further example of the US' use of science diplomacy linked to development assistance is evident in Obama's announcement that the US would, "open centres of scientific excellence in Africa, the Middle East and Southeast Asia, and appoint new science envoys to collaborate on programs that develop new sources of energy, create green jobs, digitize records, clean water, and grow new crops" (Turekian and Neureiter 2012:28). Japan, too, has been active in using science and technology in its development cooperation through projects in water and sewage systems, health and infrastructure projects such as the development of ports. As Yakushiji (2009:1) argues, "[it] is indisputable that Japan's scientific and technological capabilities have made a major contribution to this support. In other words, science and technology has formed the backbone of Japan's development assistance policies".

South Africa's cooperation with Africa is seen as a priority, where engagements with the continent reflect South Africa's position as a knowledge "producer" and exporter, aimed at creating "conditions for the development of a knowledge-based economy in Africa" and engaging with Africa in achieving "shared economic and social development in the region and on the continent" (DST 2011). Already South Africa's development cooperation with Africa includes knowledge sharing and capacity building through the African Renaissance and International Cooperation Fund (ARF) (DIRCO 2014:9-10).

There are, however, growing concerns around South Africa's ability to pursue a central position as a "producer" of knowledge within the science, technology and innovation networks as efforts are increasingly constrained by a, "fragmented research-scape, in which there [is] little communication between government, academia and industry and that, as a result, there [is] a lack of co-ordination, agenda-setting and prioritisation" (Wild 2015). This is in line with the point made in the 2010 ministerial review of South Africa's science and technology landscape, and the 2011 National Development Plan (NDP), which notes that despite, "an excellent set of science institutions, research priorities are not always consistent with South Africa's competitive advantage or growth strategy" (NPC 2011: 131).

\subsection{Science diplomacy and access to resources: South Africa as a knowledge "consumer"}

While South Africa adopts elements that reflect the position of developed states as "producers" of knowledge, it also adopts an approach to science diplomacy that reflects elements pursued by developing states that find themselves as "consumers" of knowledge within the global knowledge structure. This includes the focus 
on attracting capacity and resources from developed states. When it comes to bilateral cooperation there is an emphasis on promoting, "collaborative activities and leverage[ing] resources [...] from states outside Africa, with specific focus on developing a knowledge-driven economy" (DST 2011). This is becoming increasingly important as the country's spending on research and development has regressed as part of the percentage of GDP (Wild 2015). Indeed, the Ministerial Review Committee on the Science, Technology and Innovation (STI) Landscape noted that South Africa needs to be positioned, "strategically and as an attractive destination for science and technology collaboration, enabling the exchange of knowledge, capacity and resources with other countries" (DST 2014a:9).

There is a growing emphasis within the DST's international relations programme on leveraging resources in addressing domestic development priorities. For instance, in 2001 attention was given to elements such as benchmarking the quality of national research and development, knowledge creation and dissemination, and internationalising South African science and technology, along with leveraging international support for skills development (DST 2001). By 2013 the emphasis was squarely on promoting access to resources in three of the four identified points. This reflects the government's emphasis on attracting scientific and technological knowledge in support of "social development and poverty alleviation" (Pandor 2012).

For South Africa, as in many other developing states, there are constraints on capacity. This, in turn, limits the options for South Africa in international engagements. As the NDP sets out, "South Africa needs to sharpen its innovative edge and continue contributing to global scientific and technological advancement. This requires greater investment in research and development, better use of existing resources, and more nimble institutions that facilitate innovation and enhance cooperation between public science and technology institutions and the private sector" (NPC 2011:33).

South Africa's bilateral relations with the geo-political North have been increasingly focused on ensuring that local scientists benefit from accessing additional resources and cutting edge development in science and technology (Pandor 2012). For instance, science and technology has formed an integral part of South Africa's bilateral relations with Japan, with the DST receiving three Japanese attachés since 1996, while South Africa sent its first Counsellor of Science and Technology in 2004 (DST 2014b). South Africa has also concluded an Agreement for Scientific and Technology Cooperation with Japan and the Japan-South Africa Partnership Forum which includes science and technology for strengthening relations through cooperation in areas such as skills development, digital broadcasts, and bi-directional information transmissions (Dwinger 2010). Diplomatic relations have, however, become more "complex", following South Africa's declining of an 
economic partnership agreement, a disagreement over the terms of a loan for the financing of infrastructure programmes, and South Africa's declining of a bid by Hitachi and Toshiba to supply rail locomotives (Cornelissen 2015:201).

Engagement with strategic partners from the North has also seen the pursuit of collaboration on science and technology with the EU and its member states. While the first agreement signed between South Africa and the EU was the Science and Technology Cooperation Agreement of 1996, the emphasis for South Africa's science diplomacy remains on leveraging access to resources, as well as support for capacity building in joint partnerships with the EU on projects such as Group on Earth Observations (GEO), the SKA, and the European and Developing Countries Clinical Trails Partnership (EDCTP) (DST Seminar 2014). South Africa has also been active in bidding to participate in the EU Framework Programme (FP) since FP4 (1994-1998). From FP4-FP7 there have been more than 300 South African participants, across sectors such as health, food and agriculture, ICT, energy, the environment, nanoscience, security, transport, and socio-economic sciences, with South Africa participating in FP7 as a full partner with European Commission funding ( $\mathrm{Du}$ Toit 2009). The Framework Programme is, however, an instrument of the EU for the implementation of its own common scientific and innovation policy in building transnational cooperation. Engagement remains structural as the project proposals are submitted only in response to EU research calls and European partners are needed for participation.

\section{CONCLUSION}

Science diplomacy has strategic value in facilitating international relations and advancing science. This, however, faces the challenge of breaking through the Chinese walls of science and diplomacy; understanding the science, as well as the politics that shapes engagement and implementation. It also requires a deeper understanding of the impacts of the global knowledge structure on these relations. So, while there is indeed scope for science diplomacy to act as a "bridge" in bringing states together in cooperation on scientific advancement, the inequality present in the current global knowledge structure may see relations also becoming increasingly divisive.

Within the literature on science diplomacy there are a number of explanations and accounts of science diplomacy from the perspective of developed countries. There is less discussion and debate on the perceptions and practice of science diplomacy from emerging and developing countries. As an "emerging power", included in the same category as countries such as India, Brazil, and China on the geo-political landscape, post-apartheid South Africa reflects elements of both a developed and developing country in its pursuit of science diplomacy. The first is as 
a "producer" and exporter of knowledge looking to secure a central position within the international milieu. Here South Africa has followed a similar path to that of developed countries, exporting produced knowledge to states on the periphery of the global knowledge structure in advancing its own scientific capabilities.

Domestic realities and the emphasis on addressing the triple challenges of poverty, unemployment and inequality have, however, seen South Africa placing additional emphasis on the second track of science diplomacy. As a "consumer" and an importer of knowledge, Pretoria has engaged in negotiations to secure access to resources and to the most recent developments in science, technology and innovation. This has seen priority being given to negotiations with developed states in support of collaborative projects and in financing South African research programmes. As an emerging country, and caught between this two track approach to science diplomacy, South Africa is increasingly facing challenges as it seeks to define its role within the global knowledge structure.

\section{LIST OF SOURCES}

American Association for the Advancement of Science (AAAS) and the Royal Society 2010. "New frontiers in science diplomacy: Navigating the changing balance of power". RS Policy document 01/10, January, pp. v-vi.

Annegarn, HJ and RJ Swap 2012. "SAFARI 2000: A Southern African example of Science Diplomacy", Science \& Diplomacy, <http://www.sciencediplomacy.org/ article/2012/safari-2000>, accessed 9 July 2015.

Chasek, P and L Rajamani 2002. "Steps towards enhancing parity: Negotiating capacity and strategies of developing countries". In: I Kaul, P Conceição, K Goulven and RU Mendoza (eds), Providing global public goods. Office of Development Studies, United Nations Development Programme, <http://web.undp. org/globalpublicgoods/globalization/toc.html>, accessed 29 July 2015.

Committee for Survey and Analysis of Science Advice on Sustainable Development to International Organizations 2002. Knowledge and diplomacy: Science advice in the United Nations System. Washington D.C.: National Academies Press.

Cooper, F, J Heine and R Thakur (eds) 2013. The Oxford handbook of modern diplomacy. Oxford: Oxford University Press.

Cornelissen, S 2015. "South Africa's relations with China and Japan". In: L Masters, S Zondi, J van Wyk and C Landsberg (eds), The South African foreign policy review. Pretoria: AISA/HSRC, pp. 188-205. 
Department of International Relations and Cooperation (DIRCO) 2014. African Renaissance and International Cooperation Fund: Annual Report 2013-2014. Pretoria, <http://www.dirco.gov.za/department/african_renaissance_report2013-2014/ arf_annual_report_2013-2014.pdf>, accessed 24 November 2015.

Department of Science and Technology (DST) 1996. White Paper on science and technology, <http://www.gov.za/sites/www.gov.za/files/Science_Technology_White_ Paper.pdf $>$, accessed 21 July 2015.

DST 2001. Annual Report 2000/2001. Pretoria, < http://www.dst.gov.za/index.php/ resource-center/annual-reports?start=10>, accessed 24 November 2015.

DST 2011. "Programme 3: International Cooperation and Resources", November, $<$ http://www.dst.gov.za/index.php/internatprog>, accessed 21 July 2015.

DST 2014a. Annual Report 2013-2014. Pretoria, <http://www.dst.gov.za/images/ pdfs/ DSTAnnualReport_1314.pdf $>$, accessed 10 July 2015.

DST 2014b. Seminar on South Africa's Science and Technology Diplomacy, Pretoria, 13 May.

DST 2015. Interview with representative from the DST. Interviewed by L Masters, Pretoria 30 July 2015.

Du Toit, D 2009. "Smart electricity distribution networks: Research and innovation in South Africa". Presentation to the European-South African Science and Technology Advancement Programme", <http://ec.europa.eu/research/conferences/2009/ict-energy/ pdf/daan_du_toit_en.pdf $>$, accessed 10 July 2015.

Dwinger, F 2010. "Japan and South Africa: A chronicle of 100 years of relations", Consultancy Africa Intelligence", <http://www.polity.org.za/article/japan-and-southafrica-a-chronicle-of-100-years-of-relations-2010-10-14>, accessed 28 July 2015.

Fedoroff, NV 2009. "Science Diplomacy in the $21^{\text {st }}$ Century", Cell 139, 9 January, $<$ http://www.cell.com/abstract/S0092-8674(08)01636-X>, accessed 24 November 2015.

Flink, T and U Schreiterer 2010. "Science diplomacy at the intersection of S\&T policies and foreign affairs: towards a typology of national approaches", Science and Public Policy 37(9):665-677.

Holt, R 2015. "Scientific drivers for diplomacy", Science \& Diplomacy 4(2), June, $<$ http://www.sciencediplomacy.org/files/scientific_drivers_for_diplomacy_science_ diplomacy.pdf>, accessed 9 July 2015. 
Kramer, D 2010a. "Science diplomacy enlisted to span US divide with developing world", Physics Today, December:28-30.

Kramer, D 2010b. "At work in the trenches of science diplomacy", Physics Today, December:30-31.

Linkov, I, B Trump, E Tatham, S Basu and M Roco 2014. "Diplomacy for science: Two generations later", Science and Diplomacy, <http://www.sciencediplomacy. org>, accessed 29 July 2015.

Magwaza, N 2015. "SA citrus specialists to visit EU over black spot row", Business Day online, 23 July, <http:/www.bdlive.co.za/business/agriculture/2015/07/23/sacitrus-specialists-to-visit-eu-over-black-spot-row>, accessed 23 July 2015.

Makinda, SM, FW Okumu and D Mickler 2015. The African Union: Addressing the challenges of peace, security, and governance. London: Routledge.

National Planning Commission (NPC) 2011. The National Development Plan: Vision 2030. The Office of the President, Pretoria, <http://www.poa.gov.za/news/ Documents/ NPC\%20National\%20Development\%20Plan\%20Vision\%202030\%20 -lo-res.pdf>, accessed 24 November 2015.

Pandor, N 2012. "South African Science Diplomacy", Science Diplomacy, <http:// www.sciencediplomacy.org/perspective/2012/south-african-science-diplomacy>, accessed 9 July 2015.

Pandor, N 2014a. Address to the 2014 South African Heads of Mission Conference, Pretoria, Wednesday, 27 August, <http://www.dst.gov.za/index.php/media-room/mediaroom-speeches/minister/1054-address-by-the-minister-of-science-and-technologynaledi-pandor-mp-to-the-2014-south-african-heads-of-mission-conference-pretoria-wednesday-27-august-2014>, accessed 27 July 2015.

Pandor, N 2014b. Remarks, Sudan Bilateral Ministerial Meeting at the occasion of signing a Bilateral Science and Technology Agreement, <http://www.dst.gov.za/ index.php/media-room/media-room-speeches/minister/1171-remarks-by-naledipandor-mp-minister-of-science-and-technology-south-africa-sudan-bilateralministerial-meeting-at-the-occasion-of-signing-a-bilateral-science-and-technologyagreement>, accessed 27 July 2015.

Pandor, N 2015. Second BRICS Science, Technology and Innovation Ministerial Meeting, <http://www.gov.za/speeches/remarks-naledi-pandor-mp-minister-scienceand-technology-second-brics-science-technology>, accessed 27 July 2015. 
Simelane, T 2015. "Science and technology and South Africa's foreign policy". In: L Masters, S Zondi, J van Wyk and C Landsberg (eds), South African foreign policy review. Volume 2. Pretoria: Africa Institute of South Africa/HSRC, pp. 41-57.

Strange, S 2015. States and markets. Revelations edition, Bedford Square: Bloomsburg.

Treacy, S 2015. "Science diplomacy: a view from the South", The World Academy of Sciences, <http://twas.org/article/science-diplomacy-view-south>, accessed 25 July 2015.

Turekian, V and N Neureiter 2012. "Science and diplomacy: The past as prologue", Chemistry in Australia, December 2012/January 2013:26-29.

Vorster, S and P Nel 1995. "Tracing power relations in the global knowledge structure: two case studies", Politikon: South African Journal of Political Studies 22(1):52-78. DOI: 10.1080/02589349508705015.

Wheeler, T 2014. Presentation at the DIRCO/IGD/UNISA Symposium on the Blue Economy and Maritime Security Challenges for South and Southern Africa, DIRCO, Pretoria, November.

Wild, S 2015. "Government plays matchmaker between innovators and business", Mail $\&$ Guardian online, 2 February, <http://mg.co.za/article/2015-02-02-government-playsmatchmaker-between-innovators-and-business/>, accessed 8 July 2015.

Yakushiji, T 2009. "The potential of Science and Technology Diplomacy", AsiaPacific Review 16(1):1-7.

Zahuranec, BJ, V Ittekkot and E Montgomery (eds) 2014. Science and Technology Diplomacy in developing countries. New Delhi: Daya Publishing House. 